Indonesian Journal of Islamic Communication, Vol. 1, No. 2, Desember 2018: 87-102

\title{
EPISTEMOLOGI ANARKISME PENYIARAN ISLAM DALAM PERSPEKTIF PAUL K. FEYEREBEND
}

\author{
ADE NURWAHYUDI \\ Program Studi Komunikasi dan Penyiaran Islam \\ Institut Agama Islam Negeri Jember
}

Diunggah 30 Oktober / Direvisi 22 November / Diterima 28 Desember 2018

\begin{abstract}
Abstrac: In this paper I will discuss this philosophy with three components consisting of ontology, the third epistomology and axiology is a compendium that cannot be separated from the discussion of this paper. But in the writing of this paper we will try to present a discussion about the epistemology of anarchism in the thinking of Paul K Feyebend on the science of Islamic broadcasting. Where the development of knowledge is conveyed in the science of science and knowledge of this philosophy and in it there are several devices that are able to decipher the nature of something.
\end{abstract}

Keywords; Epistemology of anarchism, Paul Karl Feyerabend, the science of Islamic broadcasting 


\section{A. PENDAHULUAN}

Filsafat merupakan ilmu pengetahuan metodis, sistematis dan koheren tentang seluruh kenyataan. Filsafat ini adalah refleksi tentang berfikir atas keseluruhan realitas untuk mencapai hakikat (kebenaran) dan memperoleh hikmat dalam kehiduapan tentunya .

Salah satunya dalam makalah ini saya akan membahas cara pemikiran dari berberapa tokoh yang ada. Dimana salah satunya Paul Karl Fayerebend pada posisi pembahasan pertama terkait biografi beliau, cara pandang pemikirannya sampai dengan keilmuannya sampai sejauh mana pengaruhnya terhadap ilmu. Didalam pemikiran tentunya menjadi perlu untuk di jelaskan tentang anarkisme yang digunakan oleh Paul Karl Fayerebend dengan pemikirannya, terus ada lagi dengan pemikiran Thomas Kuhn dalam The Structure of Scientific Revolutions dalam analisisnya atas sejarah perkembangan sains menunjukkan bahwa perkembangan sains tidak berlangsung linier, homogen, dan rasional. Disini Sains berkembang melalui revolusi-revolusi yang membongkar paradigma lama dan menggantinya dengan yang baru.

Oleh karena dengan perkembangannya mengalami banyak sekali pertentangan dari tokoh- tokoh pemikir yang merasa bahwa teori-teori positivistik sangatlah menghegemonik pemikiran mereka dan membuat ilmu pengetahuan menjadi stagnan. diantara tokoh mengkritik dari positivisme ini tersebut diantaranya yang pertama adalah Thomas Khun dengan Revolusi paradigmanya, yang kedua adalah Karl Pooper dengan teori falsifikasinya, kemuian yang teakhir adalah Feyerabend dengan Anti metodenya yang mengkritik habis-habisan berkenaan dengan teori positivistic didalam makalah ini.

Feyerabend juga berusaha membebaskan para ilmuan dari beberapa metode. Baginya, peran metode dalam ilmu pengetahuan tidak bisa dipisahkan dengan peran ilmuan itu sendiri. Sejarah perkembangan Ilmu pengetahuan menunjukkan bahwa para ilmuan besar seperti Galileo, Newton, Eintstein dan yang lainnya, tidak terikat oleh metode-metode yang terlampau baku. Mereka berhasil memajukan ilmu pengetahuan berkat kebebasan mereka untuk merumuskan sendiri secara kritis caracara untuk melihat realitas.

\section{B. PEMBAHASAN}

\section{Biografi Paul Karl Feyerabend}


Paul Karl Feyerabend lahir di pada tanggal 13 januari tahun 1924 di Wina, Austria. Pada saat tahun 1945 ia belajar seni suara, teater, dan sejarah teater pada Institute for Production of Theater, The Methodological Reform The German Theater di Weimar. Memperoleh gelar Ph.D (Doctor Of Philosophy) dalam bidang fisika dari Wina University dan kemudian mengajar di California University. Waktu terus berlanjut selang delapan tahun tepatnya pada tahun 1953 ia menjadi pengajar di Bristol dan mengajar estetika, sejarah ilmu pengetahuan dan filsafat di Austria, Jerman, Inggris, Selania Baru dan Amerika Serikat. Puncak karirnya menjadi guru besar di Universitas California di Berkeley pada tahun 1958 dan Feyerabend meninggal dunia pada tahun 1994.

Paul Karl Feyerabend ini banyak dikenal sebagai seorang rasionalis. dimana ia juga di percaya dalam keunggulan ilmu pengetahuan yang memiliki hukum-hukum universal, berlaku dalam segala tindakan dan dapat dipertanggung jawabkan secara ilmiah. Keyakinan rasionalitas tersebut tampak dari kiprahnya pada masa itu dalam Himpunan Penyelamatan Fisika Teoritis ( $A$ Club for Salvation of Theoritical Physics). Keanggotaannya dalam kelompok tersebut melibatkannya dengan eksperimen-eksperimen ilmu alam dan sejarah perkembangan ilmu fisika. ${ }^{1}$

Setelah lulus sekolah menengah pada bulan maret tahun 1942, Feyerabend bergabung dengan Arbeitsdienst (semacam wajib militer yang diperkenalkan oleh NAZI). Untuk beberapa waktu selama di Arbeitsdienst, Feyerabend memilih untuk tetap tinggal di Jerman guna menghindari pertempuran langsung. Namun karena bosan dengan pekerjaan membersihkan barak, Feyerabend meminta agar dirinya dikirim ke tempat-tempat di mana pertempuran berlangsung. Beruntung, selama itu Feyerabend tidak pernah melakukan kontak senjata dengan musuh. ${ }^{2}$

Pada tahun 1975 tersebut Feyerabend menerbitkan "against method" dan membuatnya terkenal di antara para ilmuan di zamannya. Feyerabend mengatakan bahwa Against Methods ditulis bukan semata-mata untuk memajukan ilmu pengetahuan, namun juga demi alasan kemanusiaan. Feyerabend

1Prasetya T.W., "Anarkisme Pengetahuan dalam Ilmu Pengetahuan Paul Karl Feyerabend," dalam Tim Redaksi Drikarya, Hakikat Pengetahuan dan Cara Kerja Ilmu-ilmu (Jakarta: Grameia, 1993), 48.

2 Lihat: http://plato.stanford.edu/entries/feyerabend/ (keyword: Paul Feyerabend) pada tanggal 1610-2018, jam 10:00 Wib 
menganggap bahwa ilmu pengetahuan modern dari barat telalu memaksakan kehendaknya ke setiap penjuru dunia

\section{Pemikiran Paul Karl Feyerabend}

Pembahasan yang komprehensif atas pemikiran filsafat Feyerabend memang sulit untuk dilakukan. Di samping karena rentang gagasannya yang panjang, hal ini juga karena kecenderungannya untuk mengadopsi ide-ide tertentu pada satu waktu sekaligus mengkritik ide-ide tersebut di waktu lainnya. Tulisantulisan Feyerabend, menurut Eric dan Paul, telah ditafsirkan dengan cara yang beragam. ${ }^{3}$

Pada awalnya, sebagai murid Popper, Feyerabend mendukung filosofi dan prinsip falsifikasi Popper namun kemudian dia berbalik menjadi salah seorang penentang Popper. Feyerabend berpendapat bahwa prinsip falsifikasi Popper tidak dapat dijalankan sebagai satu-satunya metode ilmiah untuk kemajuan ilmu pengetahuan.

Feyerabend adalah seorang pemikir bercorak post-modern yang kritis terhadap keberadaan naras-narasi besar dalam ilmu pengetahuan modern. Narasi-narasi tersebut perlahan tapi pasti berubah menjadi semacam ideology yang mengatasnamakan ilmu pengetahuan. Melalui anarkisme epitemologis, Feyerabend pada dasarnya menolak kepatuhan mutlak pada metode-metode dalam ilmu pengetahuan. Baginya, apa yang dapat dicerap oleh para ilmuan hanya menggambarkan kapasitasnya untuk mengetahui, dan sama sekali tidak ada kaitannya dengan kebenaran tentang realitas itu sendiri.

Secara ringkas, pemikiran Feyerabend dapat dijelaskan sebagai kritik umum terhadap pemosisian teori dan metode oleh para ilmuan dalam rangka mengembangkan ilmu pengetahuan. Kritik Feyerabend terutama sekali diarahkan pada anggapan bahwa hanya ada satu atau setidaknya sedikit saja jalan yang mungkin ditempuh untuk mengembangkan ilmu pengetahuan. Feyerabend berpendapat bahwa hal semacam itu tidak pernah ada. Pengetahuan yang dianggap paling tidak ilmiah sekalipun, dengan satu dan lain

\footnotetext{
${ }^{3}$ Eriq Oberheim dan Paul Hoyningen-Huene, Paul Feyerabend's Early Philosophy, Essay Review, Pergamon, UK, 2000,1
} 
cara, membantu menyusun kerangka pemahaman yang lebih baik terhadap realitas.

Feyerabend menganggap bahwa falsifikasi yang digagas oleh Popper, dalam beberapa hal ini, tidak relevan dengan tujuan memajukan ilmu pengetahuan. Begitu juga apa yang disampaikam dengan revolusi pengetahuan yang digagas oleh Kuhn. Feyerabend menyebut bahwa satu-satunya jalan untuk memajukan ilmu pengetahuan adalah dengan membebaskannya dari segala macam aturan-aturan metodik yang mengikat.

Bagi Feyerabend, dengan keberadaan bermacam- macam metode-metode yang kaku tersebut telah menjadikan ilmu pengetahuan tidak dapat merubah sebuah ideology yang menentukan mana yang benar dan mana yang salah. Padahal, kebenaran tentang sesuatu harus diserahkan sepenuhnya pada objek kajian itu sendiri, tanpa memaksakan kerangka yang dibuat para ilmuan atas objek itu sendiri. Salah satunya diantaranya metodenya adalah anti metode. Artinya metode tersebut menjadi salah satu prinsip yang dapat digunakan untuk membebaskan ilmu pengetahuan dari metode-metode ilmu yang telah berubah menjadi ideology.

Fereyebend disini tidak memaksakan para pemikir-pemikir atau pradiga untuk selalu mengikutinya dala pemikiranya, namua ia hanya mencoba mencari jalan keluar atau mengritisi daya keilmuan dari metode yang ada.

\section{Anarkisme Paul K. Feyerebend}

\section{a. Pengertian Anarkisme}

Anarkisme secara umum didefinisikan sebagai filsafat politik yang memegang negara tidak diinginkan, tidak perlu, dan berbahaya, atau alternatif sebagai menentang otoritas dan organisasi hirarkis dalam melakukan hubungan manusia. Para pendukung anarkisme, yang dikenal sebagai "anarkis", advokat masyarakat bernegara berdasarkan non- hirarkis asosiasi sukarela. ${ }^{4}$

Semula Feyerabend telah mendukung terhadap filosofi dan prinsip falsifikasi Popper namun kemudian ia berbalik menjadi salah seorang penentang pemikiran Popper. Feyerabend berpendapat bahwa prinsip 
falsifikasi Popper tidak dapat dijalankan sebagai satu-satunya diantaranya metode ilmiah untuk kemajuan ilmu pengetahuan.

Dimana pada dasarnya prinsip mengenai tidak adanya metodologi yang berguna baginya dan tanpa kecuali yang mengatur kemajuan sains disebut adalah epistemologi anarkis. Salah satu metodologi tersebut dicontohkan misal metodologi empiris atau rasionalisme kritis Popper akan memperlambat atau menghalangi pertumbuhan ilmu pengetahuan. ia berkata 'anything goes' yang artinya hipotesa boleh dipergunakan, bahkan yang tidak dapat diterima secara rasional atau berbeda dengan teori yang berlaku atau hasil eksperimen. Sehingga ilmu pengetahuan bisa maju tidak hanya dengan proses induktif sebagaimana halnya sains normal, melainkan juga secara kontrainduktif.

Pengertian anarkisme ini tidak indentik dengan nihilisme, tetapi dapat ianggap memiliki kesamaan-kesamaan dengan libertarisme politik dan antinomianisme, sedangkan dalam kontanasi negatif anarkisme merupakan keyakinan tidak menghargai sedikitpun hukum atau tatanan dan secara aktif terlibat dalam meningkatkan situasi khaos dengan menghancurkan tatanan masyarakat sehingga paham ini menganjurkan penggunann terorisme perorangan sebagai sarana mempropagandakan organisasi dan poltik. ${ }^{5}$ Selain itu dalam Kamus Besar Bahasa Indonesia arti anarkisme adalah ajaran (paham) yang menentng setiap kekuatan negara, teori politik yang tidak menyukai adanya pemerintahan dan undang- undang, 6

\section{b. Anarkisme juga sebagai kritik}

Anarkisme disini yang dimaksud oleh Feyerabend bukan anarkisme seperti dalam politik melainkan anarkisme epistemologis. Anarkisme Epistemologis di pertentangkan dengan anarkisme politis atau religius. Dikatakannya, apabila anarkisme politis berarti suatu perlawanan terhadap segala bentuk kemampuan (kekuasaan Negara, institusi-institusi, dan ideologiideologi yang menopangnya), mungkin anarkisme epistemologis tidak selalu punya loyalitas ataupun permusuhan terhadap institusi-institusi itu. Seorang

\footnotetext{
${ }^{5}$ Lorwns Bagus, Kamus Filsafat ( Jakarta:PT Gremeia Pustaka Utama,1996), 48

${ }_{6}$ Pustaka Bahasa Depdiknas, Kamus Besar Bahasa Indonesia.(Jakarta:Balai Pustaka,2005), 44.
} 
anarkis di bidang ini ibarat seorang dadais. Sebagai seorang dadais, ia adalah dadais dan sekaligus dadais. ${ }^{7}$

Oleh karenanya Dadais yang merupakan gerakan para seniman yang menentang frame atas seni yang mencitrakan seni sebagai sesuatu yang elit. Para dadais menganggap bahwa seni dialah suatu kebebasan ekspresi untuk semua kalangan. Maksud dari Feyerabend tentang seorang dadais dialah dadais sekaligus anti dadais dapat dijelaskan dengan logika himpunan yang bersinggungan. Seperti halnya logika paradoks Russel tentang seorang tukang potong rambut bahwa ada himpunan yang menjadi anggota dari himpunan itu sendiri.

Fayerabend begitu menentang metode dengan argumentasi yang begitu kuat. Menurutnya, ketika menjalani sebuah riset dan mengambil sebuah keputusan, sebaiknya para ilmuan tidak bisa dibatasi sama sekali walaupun dibimbing oleh metode-metode yang sudah ada. Ia harus bebas. Dalam proses kegiatan ilmiah harus berupaya bersifat "anarkistik".

Perlu diketahui dalam pemikiran Feyerabend yang diberi nama anarkisme epistemologis merupakan sebuah kritik, atas nama kebebasan individu yang manusiawi, ia memberi kritik dari dua sisi yang keduanya tidak dapat dipisahkan satu sama lain. Pertama: Feyerabend mengkritik ilmu pengetahuan, yaitu metodenya, kritik ini diberi nama Against Methods, kedua: Feyerabend mengkritik praktek fungsi serta kedudukan ilmu pengetahuan dalam masyarakat. Kritik ini disebut sebagai Against Science dan beberapa kritik yang lainya.

Adapun metode- metode yang digunakan feyerebend dalam anarkisme epistemologis didalam mengkritisi terhadap ilmu pengetahuan diantaranya adalah :

\section{Anti Metode}

Anti metode yang menjadi ciri khas dari pemikiran Fayerabend merupakan hasil dari kritikan terhadap para ilmuan yang mengakui adanya suatu metode yang tergolong baku dan berlaku secara universal bahkan berangapan metode bisa berlaku sepanjang masa dan mampu mengatasi

\footnotetext{
7 Mudhofir, Ali.. Kamus Filsuf Barat.(Yogyakarta: Pustaka Pelajar. 2001), 164
} 
berbagai fakta penelitian, baginya hal seperti ini pada hakikatnya tidak sesuai dengan realitas yang sesungguhnya.

Bagi Feyerabend, dengan adanya keberadaan metode-metode yang kaku tersebut telah menjadikan ilmu pengetahuan tidak ada perubahan, dimana sebuah ideology yang menentukan mana yang benar dan mana yang salah pada saat itu. Oleh karena itu, kebenaran tentang sesuatu harus diserahkan sepenuhnya pada objek kajian itu sendiri, tanpa memaksakan kerangka yang dibuat para ilmuan atas objek itu sendiri. Salah satunya kontribusi Feyerebend dalam permikiranya adalah Anti metode, karena dengan demikian menjadi salah satu prinsip yang dapat digunakan untuk membebaskan ilmu pengetahuan dari metode-metode ilmu yang telah berubah menjadi ideology. Bagi Feyerabend, jika berkaca pada sejarah perkembangan ilmu pengetahuan, maka satu-satunya cara yang tampaknya tidak akan menghambat kemajuan ilmu pengetahuan itu sendiri adalah dengan membiarkan segala bidang ilmu berkembang dengan bebas tanpa dibatasi oleh metode-metode tertentu. ${ }^{8}$

Metode memang telah mejadi sasaran kritik Feyerabend sejak lama. Gagasan mengenai metode yang mengandung prinsip-prinsip yang tegas, tidak dapat diubah dan mengikat secara mutlak, menurut Feyerabend, akan kelimpungan jika dihadapkan dengan penelitian-penelitnan sejarah, terutama sejarah sains. Feyerabend menyebut bahwa tidak ada satupun cerita tunggal yang dapat menjelaskan secara sempurna perkembangan sains hingga dalam bentuknya yang terkini. Menariknya, Feyerabend menganggap hal tersebut bukanlah akibat dari kurangnya pengetahuan ataupun perhatian terhadap aspek-aspek tertentu dari objek sejarah tersebut, melainkan karena ketiadaan narasi tunggal tersebut penting bagi kemajuan ilmu pengetahuan. ${ }^{9}$

Anti metode dapat dianggap sebagai sebagai versi yang lebih ekstrim dari falsifikasi. Meski dalam falsifikasi kebenaran ilmiah senantiasa bersifat

8John Preston, Feyerabend: Knowledge, Science and Relativism, (Philosophical Papers Vol. 3, Cambridge Universtity Press, United Kingkdom, 1999), 122-123

9 Paul K. Feyerabend, Against Methods: an Outline of Anarchist Theori, (thirdeds), Verso, London, 1992),

24 
interim, tetap saja ada penjenjangan antara yang cukup benar dengan yang palsu. Dalam anti metode, semua teori memiliki kesempatan yang sama untuk menelaah realitas.

Tentunya para ilmuwan tersebut tidak dapat lepas dari latar belakang historisnya. Dimana kritik yang paling penting dalam pemikiranya tersebut didalam ranah epistemologis adalah anarkisme epistemologis. Anarkisme epistemologis tercantum dalam karangannya anti metode. Sedang pada Ilmu pengetahuan waktu itu mengandaikan adanya satu metode yang universal, yakni matematis. Semuanya bisa diukur dengan ukuran matematis dan logis. Masalah yang tidak bisa dipecahkan secara matematis tidak bisa dipertanggung jawabkan.

\section{Anti-science}

Feyerabend menganggap bahwa kebenaran bukan monopoli ilmu pengetahuan karena monopoli berdampak kepada ideologi tertutup. Mengutip Popper, "Ideologi tertutup tidak bisa difalsifikasi." Karena itu, ilmu pengetahuan harus menjadi "realisme ilmiah". Ilmu pengetahuan hanyalah salah satu usaha untuk memahami semua realitas, di mana manusia dan alam berada di dalamnya. Menurut Feyerabend kita tidak bisa mengabaikan faktor lain di luar ilmu pengetahuan. Sebagai contoh, fenomena manusia kawat yang terjadi di Indonesia dimana didalam perut seorang wanita tumbuh banyak kawat yang secara ilmu pengetahuan tidak dapat dijelaskan bagaimana hal tersebut dapat terjadi. Walaupun saat ini terdapat ilmu pengetahuan yang berhubungan dengan hal-hal tersebut seperti metafisika, namun pembuktian secara ilmiah masih diperdebatkan hingga saat ini. ${ }^{10}$

Anti ilmu pengetahuan yang dimaksud oleh Feyerabend merupakan seperangkat gagasan yang berisi kritik mendalam atas peran dan posisi ilmu pengetahuan dalam masyarakat luas. Melalui anti ilmu pengetahuan, Feyerabend berusaha membebaskan masyarakat dari ideology ilmu pengetahuan. Feyerabend beranggapan bahwa para ilmuan telah menyalahgunakan fungsi ilmu pengetahuan demi mendapatkan

${ }^{10}$ Lihat di http://blogekayusuf.blogspot.com/2008/11/pemikiran-paul-k-feyerabend-terhadap.htm pada tanggal 16-10-2018 
kekuasaan. Cara yang digunakan para punggawa ilmu pengetahuan tersebut bermacam-macam, mulai dari memanfaan system pendidikan baik dingkat sekolah negeri atau swasta.

Saintis memiliki sebuah pandangan dunia atau paradigma. Paradigma alam Semesta mekanistik Newton berbeda dengan paradigma alam Semesta relativistik Eistein tentunya. Masing-masing merupakan suatu penafsiran tentang dunia, bukannya penjelasan obyektif. Menurut Kuhn sejarah sains diwarnai oleh revolusi dalam paradigma saintifik. Saintis menerima paradigma yang dominan sampai suatu kejanggalan muncul. Saintis kemudian mulai mempertanyakan basis paradigma itu. Teori-teori baru bermunculan dan menantang paradigma dominan tersebut sampai akhirnya teori-teori baru ini diterima sebagai paradigma yang baru.

Menurut Fayerabend, sebuah hipotesa atau teori baru tidak harus memenuhi seluruh elemen dari teori lama karena hal tersebut hanyalah akan menyebabkan teori lama dipertahankan dari pada mencari teori yang benar. Mempertahankan teori lama akan mempersempit pemikiran sehingga tidak bisa membuka lahan teori yang baru dan mengarahkan ilmu pengetahuan pada subyektivitas, sentimen atau prejudis. Seperti halnya teori Quantum pada awalnya ditentang bahkan oleh Einstein "God does not play dice", karena implikasi teori ini akan menyebabkan ketidakpastian yang sangat mengganggu pemikiran.

\section{Counterinduction}

Thomas J. Kickey menyebut bahwa yang dimaksud dengan "counterinduction" oleh Feyerabend adalah praktik-praktik dalam aktivitas pengembangan ilmu pengetahuan yang sifatnya antimetodologis. ${ }^{11}$ Praktik-praktik tersebut berkaitan erat dengan gagasangagasan Feyerabend tentang anti metode, proliferasi dan 'anything goes'.

Menurut Feyerabend, counterinduction mengacu pada upaya melakukan kritik secara mendasar dengan menggunakan standar eksternal. Artinya, satu teori tertentu akan sulit untuk diidentifikasi kelemahannya selama cara pandang yang digunakan untuk menilai prinsip

11Thomas J. Hickey, Thomas Kuhn on Revolution and Paul Feyerabend on Anarchy, Twentieth-Century Philosophy of Science, h. 58 (diunduh dari http://www.philsci.com/book6-8.htm, pada 16-10-2018. 
dan elemen dari teori tersebut masih berkutat pada cara pandang lama yang memang telah digunakan oleh teori itu sendiri. Cara efektif untuk melihat kelemahan sekaligus kelebihan yang dimiliki oleh sebuah teori dalam konteks memajukan ilmu pengetahuan adalah dengan melihat objek kajian teori tersebut dengan seperangkat alternative yang sama sekali berbeda, baik prinsip maupun elemen-elemennya. ${ }^{12}$

\section{Prinsip Proliferasi}

Feyerabend mengajukan beberapa tawaran dalam konteks memajukan ilmu pengetahuan. Ia yang dulunya pernah sepakat dengan Popper membantah jika Falsifikasi saja sudah cukup untuk mengembangkan teori yang benar dalam ilmu pengetahuan. Menurutnya, menemukan teori yang benar tidak harus dengan mencari kesalahakesalahan dari sederet teori yang potensial, namun dengan membiarkan sebanyak mungkin teori-teori berkembang. Menurutnya, dengan cara seperti itulah ilmu pengetahuan akan dapat berkembang dengan bebas tanpa terikat oleh ideology tertentu. ${ }^{13}$

\section{Incommensurability}

Prinsip proliferasi dan konsep incommensurability adalah beberapa dari pokok-pokok penting pemikiran Feyerabend. Incommensurability yang dimaksud oleh feyerabend, seperti yang dijelaskan oleh Hickey, mengacu pada hubungan dari dua atau lebih teori yang saling berkompetisi dan saling menjatuhkan satu dengan yang lain. Hubungan antara teori-teori yang saling meny tersebut, menurut Feyerabend, adalah penting demi kemajuan ilmu pengetahuan. Hubungan saling mengingkari dari teoriteori, yang menjadi latar belakang munculnya incommensurability, terjadi ketika proliferasi telah diterapkan dalam proses memajukan ilmu pengetahuan. Hubungan seperti ini muncul sehubungan dengan keadaan di mana dalam menerapkan konsep- konsep dalam sebuah teori, ilmuan

\footnotetext{
${ }^{12}$ Paul K. Feyerabend, Against Methods: an Outline of Anarchist Theori, (third eds), Verso, London, 1992), 3 Dalam Jurnal M. Tahir kontribusi pemikiran filsafat anarkisme epistimologis paul $k$. feyerabend terhadap studi islam

${ }^{13}$ Ali Maksum, Pengantar Filsafat, Dari Masa Klasik Hingga Masa Postmodernisme, (Yoygakarta, Ar-Ruzz Meia, Cet. IV, 2011), 268
} 
harus melandasinya dengan prinsip-prinsip tertentu yang jika ditilik dari kaca mata teori lainnya akan menjadi tidak valid. ${ }^{14}$

\section{c. Anarkis Epistemologi}

Ketika berbicara pemikiran Fayerabend, banyak mengajukan pemikiran yang bisa dikatakan amat menentang dan tergolong baru dalam dinamika perkembangan filsafat ilmu. Ilmu pengetahuan menurut Fayerabend, di dalam proses perkembanganya pada hakikatnya tidak bisa diterangkan atau pun diatur oleh segala macam bentuk peraturan maupun sistem hukum yang berlaku. Upaya semacam itu nantinya akan sia-sia dan tidak sesuai dengan fakta yang ada. Menurut Fayerabend, perkembangan ilmu pengetahuan itu diakibatkan proses kreativitas individual, tawaran yang diberikan olehnya satu-satunya prinsip yang tidak menghambat proses pengetahuan ia menawarkan "anything goes". Fayerabend mencoba mendobrak anggapan bahwa ada keteraturan dalam dinamisasi ilmu pengetahuan, yang kemudian keteraturan dalam dinamisasi ilmu pengetahuan hendak difaktakan dalam sebuah hukum dan sistem. Hal seperti inilah dapat dimengerti ketika jika mengingat betapa begitu kompleksnya situasi dalam memperoleh pengetahuan. Oleh karena itu, tidak mungkin mengandalkan berbagai perkembangan ilmu pada suatu metodologi ataupun hukum perkembangan manapun.

Pemikiran Fayerabend banyak mengajukan pemikiran yang bisa dikatakan amat menentang dan tergolong baru dalam dinamika perkembangan filsafat ilmu. Ilmu pengetahuan menurut Fayerabend, di dalam proses perkembanganya pada hakikatnya tidak bisa diterangkan atau pun diatur oleh segala macam bentuk peraturan maupun sistem hukum yang berlaku. Upaya semacam itu nantinya akan sia-sia dan tidak sesuai dengan fakta yang ada. Menurut Fayerabend, perkembangan ilmu pengetahuan itu diakibatkan proses kreativitas individual, tawaran yang diberikan olehnya satu-satunya prinsip yang tidak menghambat proses pengetahuanya. Fayerabend mencoba mendobrak anggapan bahwa ada keteraturan dalam dinamisasi ilmu pengetahuan, yang kemuian keteraturan dalam dinamisasi

\footnotetext{
14Paul Hoyningen-Huene, Paul K. Feyerabend: An Obituary, (terj. Eric Oberheim dab Daniel Sirte), 10-11
} 
ilmu pengetahuan hendak difaktakan dalam sebuah hukum dan sistem. Hal seperti inilah dapat dimengerti ketika jika mengingat betapa begitu kompleksnya situasi dalam memperoleh pengetahuan. Oleh karena itu, tidak mungkin mengandalkan berbagai perkembangan ilmu pada suatu metodologi ataupun hukum perkembangan manapu tentunya.

Fayerabend begitu menentang dengan metode yang argumentasi begitu kuat. Menurutnya, ketika menjalani sebuah riset dan mengambil sebuah keputusan, sebaiknya para ilmuan tidak bisa dibatasi sama sekali walaupun dibimbing oleh metode-metode yang sudah ada. Ia harus bebas. dalam proses kegiatan ilmiahnya.

Dalam pandangan Fayerabend, pandangan masyarakat tentang ilmu pengetahuan memiliki posisi yang sama dengan agama pada masa abad pertengahan. Karena masyarakat memiliki kebebasan memilih ilmu agama, bahkan dalam sebuah lingkungan masyarakat tertentu memiliki kebebasan memilih beragama dan tidak beragama. Mau tidak mau sebuah masyarakat harus mempelajari ilmu pengetahuan. Fayerabend sangat mendukung betapa pentingnya kebebasan manusia ketika memperjuangkan sebuah pengetahuan, gagasan seperti inilah Fayerabend begitu mendapat inspirasi yang besar dari pemikiran Mill.

Berbicara kesamaan antara Kuhn dan Fayerabend sesungguhnya terletak pada ilmu-ilmu atau teori tidak bisa diukur dengan standar yang memiliki kesamaan yang sama. Pandangan Fayerabend tentang observasi, harus disesuikan dengan kontekstualisasi sebuah teori. Dengan pandangan seperti inilah Fayerabend mencoba menantang untuk memisahkan antara teori dan observasi.

\section{d. Relevansi Feyerebend terhadap penyiaran Islam}

Setelah membaca anarki epistemologis dari Paul Karl Feyerabend di atas maka kiranya ada semangat atau spirit yang bisa kita ambil, spirit dari inti pembacaan pemikiran di atas adalah kebebasan individu dari pemberhalaan kekuasaan atau autoritinisme. Tapi tetap menjaga semangat yang tidak anginanginan atau asal-asalan alias bebas tapi harus bertanggung jawab, boleh nakal tapi tidak mengganggu, atau apabila dijelaskan dengan kata-kata maka 
bunyinya adalah "boleh tidak begini atau begitu tapi harus bertanggung jawab dan berseia terus merevisi menjadi yang lebih baik.

Epistemologi anarkisme yang diusung oleh Fayerabend di atas dapat dikelompokkan pada bentuk pemikiran postmodernisme berdasarkan pemilahan bidang Filsafat Ilmu, yang mengkritik ide-ide pemikiran filosof era modern seperti halnya Jean-Francois Lyotard yang menolak kebenaran tunggal universal, karena menurutnya yang ada adalah kebenaran-kebenaran. Bagi postmodernisme, cara berpikir totalitas, universalitas dan kemapanan merupakan ide dari kelompok modernisme yang memang ingin mengusung ambisi untuk menjelaskan segala sesuatu dan segala aspeknya melalui sebuah teori besar (grand theory). ${ }^{15}$ Artinya konstruk pemikiran yang kontroversial antara kelompok modernisme dan postmodernisme berawal dari kejenuhan dan ketidakpuasan akibat cacat yang diciptakan oleh modernitas. Hal itu tampak dengan menjamur dan suburnya sentralisme, birokratisme, imperialisme, hegemoni dan dominasi.

Dari semua bentuk pengingkaran tersebut, Feyerabend sejatinya ingin menyatakan bahwa ilmu pengetahuan hanya merupakan salah satu gagasan terbuka dan plural dari sekian banyak ideology yang ada dalam masyarakat. Dengan begitu, Feyerabend ingin mengatakan bahwa ilmu pengetahuan itu bukanlah ideology yang berisi omong kosong belaka dan ilmu pengetahuan menjadi pemikiran tunggal mutlak karenaadanya propaganda dari para ilmuwan dan institusi terkait yang diberi wewenanguntuk selalu mempengaruhi kesadaran kolektif masyarakat tentang hakikat dan ilmu pengetahuan itu sendiri

Maka tidak wajar mendewa-dewakan ilmu pengetahuan sebagai satusatunya pengetahuan yang paling unggul dan bahkan paling menentukan kehidupan masyarakat. Karena masalahnya terletak padamuatan ideologis dari komunitas para ilmuwan dan pihak-pihak yang selalu berusaha menciderai kemurnian citra ilmu pengetahuan dengan kepentingankepentingan subyektif, individual yang menyebabkan proses idealisasi ilmu pengetahuan yang sebenarnya mengalami stagnasi. Mungkin inilah situasi

${ }^{15}$ Noeng Muhadjir, Filsafat Ilmu; Positivisme, Postpositivisme dan Postmodernisme. (Yogyakarta: Rake Sarasin, 2001), 212. 
yang dikatakan oleh Richard Rorty bahwa epistemologi is dead, atau dalam konstruksifilsafat Feyerabend disebut sebagai anti ilmu pengetahuan (Against Scince) salah satunya itu.

\section{KESIMPULAN}

Dari berbagai uraian di atas makalah tersebut dapat disimpulkan, bahwa filsafat ilmu yang dikembangkan oleh Fayerabend terlihat dari metode yang diterapkan sangat dinamis dan memberikan kebebasan kepada ilmuwan untuk mengembangkan suatu teori tanpa terjebak oleh berbagai macam aturan yang mengikat terhadap metode. Dimana menurut pandanganya Fayerabend memunculkan metode- metode keilmuan dengan berbagai macam pendekatan tentunya, Oleh sebab itu proses pengetahuan itu harus melalui beberapa metodemetode yang terus menerus tanpa ada yang mematikan potensi yang dimiliki para ilmuwan. dan memberikan kebebasan kepada ilmuan untuk mengembangkan suatu teori tanpa terjebak oleh berbagai macam aturan yang mengikat terhadap metodenya.

Ini berati keberatan dan problem yang dihadapi oleh Feyerabend berkaitan dengan kebebasan ilmiah dan tanggung jawab etis atau sosial. Untuk ilmu sosial, hukum alam yang absolut tidak pernah menjadi premis mayor, dari dedusi ilmiah, ilmu-ilmu sosial berurusan dengan kebebasan manusia, sejarah, dan tradisinya.

\section{DAFTAR PUSTAKA}

John Preston, Feyerabend: Knowledge, Science and Relativism, (Philosophical Papers

Vol. 3, Cambridge Universtity Press, United Kingkdom, 1999)

Lihat: http://plato.stanford.edu/entries/feyerabend/ (keyword: Paul Feyerabend) pada tanggal 16-10-2018, jam 10:00 Wib

Lihat di http://en.wikipeia.org/wiki/Epistemological_anarchism, Tanggal, 16-102018, Jam: 11:00, Wib

Lorwns bagus, Kamus Filsafat ( Jakarta:PT Gremeia Pustaka Utama,1996)

Mudhofir, Ali.. Kamus Filsuf Barat.(Yogyakarta: Pustaka Pelajar. 2001)

Noeng Muhadjir, Filsafat Ilmu; Positivisme, Postpositivisme dan Postmodernisme. (Yogyakarta: Rake Sarasin, 2001)

Paul Hoyningen-Huene, Paul K. Feyerabend: An Obituary, (terj. Eric Oberheim dab Daniel Sirte) 
Paul K. Feyerabend, Against Methods: an Outline of Anarchist Theori, (third eds), Verso, London, 1992, h. 3 Dalam Jurnal M. Tahir kontribusi pemikiran filsafat anarkisme epistimologis paul $\mathrm{k}$. feyerabend terhadap studi islam

Prasetya T.W., "Anarkisme Pengetahuan dalam Ilmu Pengetahuan Paul Karl Feyerabend," dalam Tim Redaksi Drikarya, Hakikat Pengetahuan dan Cara Kerja Ilmu-ilmu (Jakarta: Grameia, 1993)

Pustaka Bahasa Depdiknas, Kamus Besar Bahasa Indonesia.(Jakarta:Balai Pustaka,2005)

Thomas J. Hickey, Thomas Kuhn on Revolution and Paul Feyerabend on Anarchy, Twentieth-Century Philosophy of Science, h. 58 (diunduh dari http://www.philsci.com/book6-8.htm, pada 16-10-2018.

Eriq Oberheim dan Paul Hoyningen-Huene, Paul Feyerabend's Early Philosophy, Essay Review, Pergamon, UK, 2000, 